\title{
Character Education Based on Sumang in SMA Negeri 15 Takengon Binaan Nenggeri Antara Aceh Tengah
}

\author{
Heni Susanti \\ Graduate School \\ Universitas Negeri Yogyakarta \\ Yogyakarta, Indonesia \\ heni.susanti2016@student.uny.ac.id
}

\author{
Dyah Kumalasari \\ Graduate School \\ Universitas Negeri Yogyakarta \\ Yogyakarta, Indonesia \\ dyah_kumalasari@uny.ac.id
}

\begin{abstract}
This paper to describe the integration of sumang values in the implementation of character education programs in SMA Negeri 15 Takengon. The results indicate that SMA Negeri 15 Takengon Binaan Nenggeri Antara Aceh Tengah has integrated the values of local wisdom sumang on the implementation of character education programs based on religious values based on Al Quran and Hadith. Sumang refers to the principles, norms, and rules that are rooted in social interaction. The values of local wisdom are integrated in the form of practices, norms and regulations that apply in the school environment.
\end{abstract}

Keywords-character education, local wisdom, sumang.

\section{INTRODUCTION}

Recently, Indonesia is experiencing a crisis in various dimensions of life that are so complex. The problems that arise in Indonesia is moral degradation, such as promiscuity, drug abuse, acts of violence, chaos, bullying, pornography, waning behavior, loss of diversity, plagiarism, lack of togetherness and cooperation in the lives of Indonesian people [1] Accordingly, those mentioned problems indicate that this nation is in trouble with low moral or character. No exception, the issue of moral crisis also occurred in the district of Aceh Tengah. The manners decline, fight among the students, wild-races, smoking, drug abuse, gambling and promiscuity are increasingly prevalent among students. In that sense, those problem breaks the prevailing norms in the local area and are not in accordance with the rules of syariat religion prevailing in the province of Aceh.

Based on the problems that occur in the education recently, concerning learners who are still far from the expectations and goals of education. The education process should always be evaluated and improved. One effort to improve education is the emergence of the idea of the importance of character education in Indonesia. Character is a distinction between human beings and other living things. Humans with strong character and both individually and socially are human beings who have good morals, morals, and good manners [2] Given the importance of character education, in this case the role of educational institutions has a responsibility to inculcate them in school activities and learning process. Schools should build positive student characters so that they not only produce good generations in academic (cognitive), but also in the moral (affective) [3]. In recent years, the education has begun to socialize the value of local wisdom as a guide or a foothold in enriching the education. This movement is motivated by the belief that modernity with all its sophistication is not enough to deliver people in living a meaningful life towards happiness [4]. The development of local wisdom-based education was rooted on the belief that every community has certain strategies and techniques developed to live the life in its context.

Aceh is a special region. The special area is related to the territory which is the privilege in the field of religious, culture, education and the role of Muslim religious teacher (ulama) as regulated in UU No 44 of 1999. Aceh has the right to regulate and deal with religious, cultural and educational issues. Based on the regulation, educational institutions are granted the freedom to conceptualize education design in accordance with the purpose of educational provision set forth in the Aceh Qanun No 11 of 2014 on the provision of education in Aceh to develop all potential learners in order to realize an independent Acehnese society, civilized and dignified according to religion [14].

The implementation of Aceh education aims to develop all the potential learners into human beings who believe and piety to God, have a noble character, knowledgeable, intelligent, skilled, capable, creative, independent, democratic and responsible. Furthermore, this religion also regulates the implementation of Aceh Government School of Development. Educational institutions in Aceh have the right to organize and arrange special curricula in schools, provided they are not contrary to the objectives of the regional curriculum and the goals of the national education curriculum.

Aceh Tengah district is one of the areas that still maintain the values of local wisdom, where it becomes the norm of norms that apply in everyday life in answering the problems that occur in society. This local wisdom must be well managed to maintain the negative 
influence of external culture that can affect the existence of regional culture as one of the important potentials in the development of the nation's character. Many schools do not know yet that local wisdom values that exist in the community can be absorbed as part of the school in the implementation of character education. It's time for schools to hold the local wisdom as the basis of character education.

SMA Negeri 15 Takengon Binaan Nenggeri Antara Aceh Tengah is one of the schools in the district of Central Aceh which in this case has a curriculum built in carrying out character education. The concept of character education in SMA Negeri 15 Takengon Binaan Antara Aceh Tengah is inseparable from the rules of religion, customs and culture based on local wisdom. The development of local wisdom-based education rests on the belief that every community has certain strategies and techniques developed to live life in context.

Based on the description above, this research seeks to see how the integration of local wisdom values in the implementation of character education programs in SMA Negeri 15 Takengon Binaan Nenggeri Antara Aceh Tengah. Recognizing the importance of local wisdom as the basis of character education. The need for an idea that will become a grand design model character education based on local wisdom.

\section{CHARACTER VALUE IN LOCAL WISDOM}

Indonesia is a country rich in religious, cultural, and linguistic diversity with noble values as local wisdom. Local wisdom can be interpreted as a view or way of life, advice, proverbs, and values of a living and respected tradition, practiced by the community. Local cultural wisdom can also be used to solve the problems that are occurring within the scope of their respective cultures. Cultural diversity of the area is one of the potentials that can shape the character and image of culture itself in each region and is considered as an important part in the framework of image formation and cultural identity of a region.

Local wisdom can be understood as the idea, values, views of the local area that is wise, full of wisdom, good value, which is embedded and followed by members of the community. The richness of the cultural heritage and the value of local wisdom that develops from generation to generation is a very rich source. Local wisdom is the main capital in the formation of national identity and character. Therefore, it is necessary to revitalize the values of local wisdom by reviving and placing it in the contemporary context. These values can be seen from the traditions of the Indonesian nation such as cooperation, discipline, timely, willing to sacrifice, mutual respect and tolerance [5].

Local wisdom is often called local knowledge, local culture or local genius. Local wisdom can be interpreted as a life view and knowledge as well as various life strategies that manifest the activities undertaken by local communities in answering various problems in meeting their needs, covering aspects of religious life, science, economics, social organization, language and communication and art can be in the form of tradition, the proverbs or the motto of life. The system then becomes part of the way of life they make a habit [6].

Based on the strategy of character building and nation character issued by Directorate of National Development and Nation, Directorate of Cultural and Artistic Value, Ministry and Tourism, there are four elements as the forming element of character and nation character that is, noble values, character, character and identity. The noble values in question are all values relevant to the development of society, whether cultural, political, economic and ethical and aesthetic values contained in an ethnic community. Examples such as hard work, cooperation, honest, fair, sportsmanship that needs to grow.

Character education can be interpreted as an effort to encourage students to grow and develop with the competence of thinking and sticking to moral principles and have the courage to do the right, despite faced with various challenges [7]. Character education is not limited to the transfer of knowledge about good values but reaches out to make them embedded and integrated into the totality of thoughts and actions [8].

Local wisdom needs to be developed into an integral part of the education curriculum in all types and levels. In the Teaching for Wisdom Through History: Infusing Wise Thinking Skills in the School Curriculum, Sternberg, Jarvin dan Reznitskaya [9] stated that schools can help develop wisdom. The conceptions of local wisdom passed down through generations through fairy tales, legends, culture (adat)inducement is a strategy of transforming values that are considered important for children. Education in its broad meaning includes guidelines to live life wisely, so as not to hurt the degree of human glory as the holder of trust in managing the natural resources given by God [10].

\section{INTEGRATION OF THE VALUE LOCAL WISDOM IN SMA NEGERI 15 TAKENGON}

Discussing about Aceh's education, then education will be directed to the values and norms inherent in the diversity of Aceh culture with the breath of Islamic values. So also, with the local wisdom of the people of Aceh. Local wisdom in Aceh society is very rich and covers various aspects of life such as religion, culture, education, politics, economy, law and so on. For the people of Aceh to adhere to Islam, the religion, culture and local wisdom are an integral part of everyday life.

Local wisdom encompasses the whole life of the people of Aceh. The values contained in local wisdom are often not written or explicit but are recognized for 
their existence. Values are normative benchmarks that affect humans in their choice between ways of acting in activity. The most important part in the consideration of moral values, culture and character is the involvement of normative values prevailing in society and sanctions related to emerging issues develop the skills necessary to respond to challenges, and encourage attitudes, motivations, and commitments to make the right decisions Comprehensive lifelong lifestyle and give moral responsibility to learners who at any time change according to the demands of the times [11].

The concept of culture is a system of ideas that are shared by the support community that includes, beliefs, knowledge, values and ethics, morals are lived, done, obeyed and preserved. In cultural systems can be regarded as the result of action and as an element that influences the next action. Culture as the creation and development of values encompasses everything that exists in the physical, personal, and social realm, which is perfected to be actualized by humans and society [12].

The Indonesian nation consists of various ethnic, cultural, and various local wisdom. Culture is a role to build and form an education system, because there is no education that does not enter the cultural element. The way students learn is part of the culture and so are the forms that work on the part of the culture. Thus, culture is never separated from education itself. One of the customs in Indonesia is Gayo tribal customs that are transformed into pre-modern society's behavior into modern society in today's globalization era [13].

SMA Negeri 15 Takengon Binaan Nenggeri Antara using two curriculum that became the basis in implementing character education that is national curriculum and self-developed curriculum designed by the school. The targeted curriculum emphasizes that all activities in the school are directed towards character building. This special curriculum is tailored to the needs of the region. Gayo customs community culture with the values of character education such as sumang Integration of local wisdom values is contained in the target curriculum. Of the 18 values of character researchers will focus on religious values as the main value of the priority in the implementation of character education and integrated values of local wisdom.

The focus of SMA Negeri 15 Takengon Binaan Nenggeri Antara Aceh Tengah is the improvement of morals and moral of learners. This is in accordance with the Vision of State Senior High School 15 Negeri 15 Takengon Binaan Nenggeri Antara is "Creating the son of the nation's Muslim intellectual, morally praised, skilled, cultured, and globally based on the foundations of Faith and Piety. With the Unicode Indicator referring to the organization of intellectual education, the improvement of academic achievement based on Islamic values.
Gayo community is one of the indigenous tribes that inhabit the highlands of Aceh Province, divided into four districts (Aceh Tengah, Bener Meriah, Gayo Lues and Aceh Tenggara) occupying the second largest position as indigenous people in Aceh. In the context of the Gayo community, local wisdom is summarized in the concept of edet or custom that includes the practices, norms and demands of social life derived from the experience that has been through Islamization. The form of local wisdom in Gayo society includes Gayo language, governance system (sarakopat), social norm (sumang), aesthetic expression (art), and the concept of Gayo cultural basic values [13].

The dimensions of local wisdom in the Gayo community are summarized in the basic values of culture that represent the philosophy, outlook and ideal character to be achieved. Referring to Melalatoa classification there are seven values of Gayo culture, where there is one peak value which is a representation of local wisdom based on Islamic values. Gayo cultural value system places self-esteem (mukemel) as the primary value. To achieve that level of self-esteem, one must practice or refer to several supporting values: discipline (tertib), commitment (setie), sympathy (semayang gemasih), democratic (genap-mupakat), empathic (alang-tulung), professional (mutentu), integrity (amanah). To realize the development of the seven supporting values, need to drive value, which according to Melalatoa called the competitive spirit to do good, (bersikemelen) [4].

Inventory of local wisdom is concerned with how educators with educational stakeholders make efforts to identify local wisdom. The next stage is the need to sort out which aspects of local wisdom are most urgent and relevant to be developed. This selection is necessary because schools with large missions are expected to prepare learners to get jobs, good citizens preparation, self-actualization containers, and others [4].

This sumang concept is now being integrated into the concept of character education in SMA Negeri 15 Takengon Binaan Nenggeri Antara Aceh Tengah which refers to religious values. SMA Negeri 15 Takengon Binaan Nenggeri Antara choosing sumang as a community norm that is considered urgent and relevant to be developed in the developed curriculum in the framework as a solution to answer, anticipate, and minimize the problem of moral crisis among students.

The observance and implementation of Gayo customs values as described above, Gayo society has for centuries and now maintained a system of association contrary to Islamic values and norms and customary values. The social process cannot be separated from the way and purpose of talking, sitting, walking and seeing or looking. Because in Gayo customs is prohibited to do work which is considered not good sumang. 
Sumang is an act or behavior that violates the values and norms of Islam in Gayo customs. Sumang is a regulation in the form of prohibition in association between men and women. In addition to being contrary to religion, custom, also in terms of morality or deeds it is considered not commendable. Sumang consists of sumang kenunuken, perceraken, pelangkahen and sumang penengonen: (1) sumang pelangkahan (it's not permit to go with non-mahram together everywhere); (2) sumang percerakan (it's mean must be saying politely) (3) sumang penengonen (do not permit to look at the things in spesial rules in Muslim culture); (4) and sumang kenunlen (not permit to stay in one place together with non-mahram).

Local wisdom sumang gayo tribe for which is part of principles, norms and rules of the form tangible in social interaction. In the context of Gayo community itself local wisdom is summarized in the concept of custom (edet) which includes the practice, norms and demands of social life. SMA Negeri 15 Takengon Binaan Nenggeri Antara Central Aceh trying to integrate the values of local wisdom in the form of practice, the norm in the school environment life include:

- Sumang pelangkahan among the students of SMA Negeri 15 Takengon Aceh Tengah are prohibited from dating which includes a violation that has been regulated in the credit points / contract students by the school.

- Sumang percerakan such as reducing unnecessary conversation, not being rude, and raising a voice when talking to a teacher or an elderly person.

- Sumang penengonan such as clothing should be neat, for female student's hijab (veil) should not be thin, clothes should be long and should not be excessive in terms of decorating themselves.

- Sumang kenunulen forbidden to gather between female and male students if not in terms of discussing lessons, forbidden to ride with nonrelatives. Seen clearly with the separation of the parking lot of the bicycle / motorcycle, and the park read male and female students.

It aims to avoid the things that are not desirable. The rules are made based on the provisions of the Qur'an Qs. Al-isra verse 32 which became the main reference source of the application of religious character values in accordance with Aceh culture. Religious values set out in the school discipline documents include; (1) it is prohibited to overdo it in self-decoration; (2) uniform should not be short; (3) the hijab should not be thin; (4) may not upload photos on social media without using hijab; (5) prohibited from going out (6); obligate to pray dhuha (7); dzuhur prayer in congregation (8) speaks politely, not in a loud voice; (8) shall memorize a short letter; (9) and strictly prohibited from bringing VCDs, pornographic images into the school environment. Carrying VCD, pornographic images and performing immoral acts are included in serious offenses. The penalty given is the release of the student from school.

Sumang became the basis of moral and moral education in SMA Negeri 15 Takengon Antara Aceh Tengah. The punishment for students who violate the rules is also adapted to mukemel value (self-esteem or shame culture) within Gayo society. This is seen in school practices, any student who commits an offense will be punished in front of all students and teachers with the aim of causing a deterrent effect and a lesson for other students not to commit the same mistake. According Melalatoa concept mukemel with respect to self-esteem [4]. The term mukemel basically means shame. In its embarrassed application is understood in a broader sense, thus including the meaning of selfesteem in the concept of moral study. This concept refers to the ability to keep yourself from falling into thoughts and actions that can lead to the loss of selfesteem. A person who has a mukemel attitude consistently maintains self-esteem by preventing himself or his family from being trapped in disgraceful acts or contrary to religious guidance syariat and customary norms (customs).

At the application stage, local wisdom must be demonstrated by the principal, teachers, and education personnel, so that it really becomes a school culture. There is a synergy between principals and teachers in implementing character education in SMA Negeri 15 Takengon Binaan Nenggeri Antara Aceh Tengah. If there is synergy, then the hope of the realization of a character school will be successfully achieved. Local wisdom is the cultural representation of a community articulated in both visible and invisible form. The hope of the government, especially the ministry of education and national culture can intensively pay attention, prioritize the development of local wisdom as a potential improvement of the nation's character. By providing training facilities, research on the character education model based on local wisdom to realize the quality of character education.

\section{CONCLUSION}

The concept of character education in SMA Negeri 15 Takengon Binaan Nenggeri Antara Aceh Tengah based on religious values based on Al-Quran and Hadith and integrating the value of local wisdom of sumang in the implementation of character education. Long before the government socialize the values of the character of the nation, Gayo community since centuries ago is familiar with the value system that has become the principle of Gayo tribe in the social order of the local community.

The effort to unearth the heritage of the predecessors whose condition with the value of wisdom and wisdom is one of the potentials that can answer the problems of the nation, especially the character education problem. Local wisdom becomes an option that should be considered in character education that is 
currently being intensified by the ministries of education and culture. Indonesia as a plural country that has a diversity of cultures, languages, customs, tribes it's time to pay attention to the uniqueness of local wisdom. In order to realize the quality education should be local wisdom placed as the base model and character education implementation in Indonesia.

\section{REFERENCES}

[1] Johansyah, "Menyelamatkan generasi muda kita", Serambinews.http://aceh.tribunnews.com/2018/06/21/menyel amatkan-generasi-muda-kita, 2018.

[2] Nasrullah, F., J., "Pendidikan Karakter pada Anak dan Remaja”, Makalah disajikan dalam Seminar Psikologi dan Kemanusiaan, di Universitas Muhammdiyah Malang, 2015.

[3] Amri, S., Jauhari, A., and Elisah, T.," Implementasi pendidikan karakter dalam pembelajaran," Jakarta: Prestasi Pustkararay, 2011.

[4] Musanna, A., "Rasionalitas dan Aktualitas Kearifan Lokal Sebagai Basis Pendidikan Karakter," Jurnal Pendidikan dan Kebudayaan, 17 (6), 2011

[5] Alfian, M., "Potensi Kearifan Lokal dalam Pembentukan Jati Diri dan Karakter Bangsa" Prosiding the 5th International Conference on Indonesian Studies Ethnicity and Globalization, 2013.

[6] Permana, Eka, C., "Kearifan Lokal Masyarakat Baduy Dalam Mengatasi Mitigasi Bencana”, Jakarta: PT Gunara Kata, 2010.

[7] Creasy. "What is Character Educaton?", dalam Educational Policy, Vol 3., 2008.

[8] Dimerman, S., "Character is the key (how to unlock the best in our children and ourselves", Canada: John Wiley \& Sons Canada, Ltd, 2009.

[9] Sternberg, Robert, J., Jarvin, Linda., Reznitskaya, Alina, "Teaching for Wisdom Through History: Infusing Wise Thinking Skills in School Curriculum" dalam Ferrari, Michel., Potworowski, Georges., Ed., Teaching for Wisdom: CrossCultural Perspectives on Fostering Wisdom. Netherland: Springer, 2008.

[10] Reagen, T., "Non-Western Educational Traditions: Indigenous Approaches to Educational Thought and Practice Third Edition", New Jersey: Lawrence Erlbaum. 2005

[11] Yusoff, N., Awang, I., A., and Ibrahim, "Integrasi Nilai Islami Dan Budaya Aceh Berdasarkan Kurikulum Karakter", Humanis, XIII (1), 2014.

[12] Koentjaraningrat, "Pengantar Ilmu Antropologi", Jakarta: Rineka Cipta, 2010

[13] Ibrahim, M., "Nilai-nilai pendidikan Islam dalam Aadat Gayo", Banda Aceh: Al Mumtaz Institute, 2013.

[14] Pemerintah Aceh, Qanun Aceh Nomor 11 Tahun 2014 tentang Penyelenggaran Pendidikan, 2014. 